\title{
Beginning of an end in Indian Ocean
}

\author{
Dr. Hasan Yaser Malik
}

\begin{abstract}
The Mackinder's seventh century old theory of Heartland stills provesits geopolitical value as it emncompsesCentral Asia,Caspian Region and Asiatic Monsoon Rimland. The Indian Ocean at confluence of Pangaea futhur enhances the value of Heartland by allowing it to share its energy resources with offshore and outlaying islands of UK, Japan and Americas respectively. All the regional and extra regionalpowers are endeavouring to win the Great Game by sharing the maximum of the Central Asian and Caspian energy resources. Since the withdrawl of UK from the east after world War II the U.S has been trying to dominate the Indian Ocean Region but the emergence of China as a world economic power is manifasting various concerns for the U.S. In order to contain the emerging China the U.S has announced to shift his naval assests to Pacific Ocean and is backing its allies like Australia, Indonesia and India to secure the sea lines of coummunications for securing its interets in the Indian Ocean. Since China has adopted its 'Stirngs of Pearls' strategy to secure its sea lines of communications and construction of Gwadar Port at gate of energy distributing choke point at of Hurmoz Strait has raised the U.Sapprehensions about the possible Chinese naval build up as it can off set the U.S domination at choke point of Malacca Strait. The Chinese plan to construct Kra Canal in the southern Thailand to link Bay of Bangal with the South China Sea, by Passing the U.S dominated Malacca Strait which can cause a power struggle allacross the oceanic region.
\end{abstract}

Key words: Heartland, Indian Ocean, Sea Lines of Communications, chokepoint,harmonious ocean and archipelago.

\section{Geography}

The Indian Ocean is the third largest, covering almost 20 percent planet's water. In its north is Asiatic Monsoon, Australia in east, Antarctic in south and African Coast on its western fringes. Indonesian archipelago serves as a boundary between two oceans around $146^{\circ}$ east meridian. Its northern extent is Hurmoz Strait. Maximum oceanic width in south is $10,000 \mathrm{~km}$ with an area of $74.92 \times 10^{\wedge} 6 \mathrm{~km}^{\wedge} 2$ (Qasim, 1998:1).It encompasses island countries like Comoros Madagascar, Maldives, Mauritius, Seychelles and Sri Lanka with Indonesian archipelago on the eastern flanks. The tri crustal plates congregate at Rodrigues Triple Point. The average length of continental shelves is 200 kilometers with exclusion of Australian western coast, where the shelf exceeds $10,460 \mathrm{~km}$. The oceanic middling deepness is $3873 \mathrm{~m}$ with an enigmatic trench called as Diamantina Trench at the depth of 8047m (Raj Narain Misra, 1986: 22). Indian Ocean has negative water balance; it receives $6000 \mathrm{~km}^{\wedge} 3$ of river water run-off and $88000 \mathrm{~km}^{\wedge} 3$ of precipitation and evaporates 103,000 $\mathrm{km}^{\wedge} 3$. The highest evaporation is at Arabian Sea decreasing towards South East (Qasim, 1998:4).

\section{Major Oceanic Landmarks}

The Indian Ocean is unique as it is mainly land locked and remains warm throughout the year (Qasim, 1998:3).Key bottle necks are Bab el Mandeb, Hormuz, Lombok, Palk and Malacca Strait. Seas include Mozambique Channel, Red, Arabian, Laccadive, Andaman and Great Australian Bight (Hanks, 1980: vii). Aden and Persian Gulf's are the further extensions. It is linked to Atlantic by way of Suez approachable through Gulf of Aden. Chief anchorage is Singapore, most engaged and is situated in to Malacca (Port Singapore Authority, 1965:32). Key anchorages are Chittagong, Colombo, Hambantota, Mumbai, Gwadar Karachi and Dubai Port World. Gwadar port is geographically part of oil rich Hurmoz Strait and yet out of the bottle neck whereas Mandeb regulates the shipping to Atlantic. Key African docks are Port Sudan, Mombasa, Dares Salaam, and Zanzibar which is especially famous for its spice export, Beira, and Port Louis. main oceanic Sea Lines of communications (SLOCs) runs between three key bottle necks; Bab el Mandeb, Hurmoz Strait and Malacca Strait (Hahn, 2000:2).

\section{Strategic value of Indian Ocean}

Its littoral states includes; African 15, Asian 24, Australia 4 and Oceanic 2. Inaugural of Suez in 1869 invigorated Europeans interests in Asiatic Rim land (Sharma, 2007:60), but mostly remained ineffective in founding trade supremacy (Wilson, 1933:54). Subsequent to World War II Russia and United States (U.S) substituted United Kingdom (UK) in the east. The U.S has always strained to create supremacy in the ocean by establishing them marine bases whereas developing littoral states less India have striven to make it a "zone of 
peace" so as to carry on with free shipping. The U.S has an armed base located at Diego Garcia; in oceanic center (Hahn, 2000:7).

The Indian Ocean offers prime SLOCs linking with Europe, Middle East, Africa, Asia and Americas through Europe. It provides 40\% of petroleum from the Persian Gulf oil fields and Indonesia (Shojai, 1995:6). Large hydrocarbon reserves from Middle East, Iran and Western Australia combined with energy reserve of Central Asian Republics (CARs) have caught the attention of all regional and extra regional key players for the 'New Great Game'. The sailing of comparatively superior flow of energy vessels has invited the piracy at African Coast. Strategically Indian Ocean can be divided into three separate regions.

\section{Arabian Sea Region}

Indian fuel requirements combined with fiscal prospect are housed in Afro - Asian Region. The safety concerns for India and SLOCs because of traditional adversary between India and Pakistan hinging over a just resolution of Kashmir issue (Matinuddin India- Pakistan Standoff Regional Offices Journal Vol. XXI, No.3, 2003:27-28). It is impending to resolve the Kashmir dispute between two arch nuclear rivals along the oil carrying SLOCs between Hurmoz and Malacca Strait for a safe global trade in harmonious waters of Indian Ocean Region.

\section{Central Indian Ocean Region}

It is in the domain of Indian inspiration for its power projection. Whole water span is vibrant for inclusive security of SLOCs and coastal areas. India needs to improve its relations with neighbouring littoral and non-littoral states. Peace and stability in the Indian Ocean is pivotal for financial security of complete Indian Ocean Region.

\section{Bay of Bengal and Malacca Strait}

India needs premeditated power in the ocean to counter China for which it seeks the help of U.S. Security of SLOCs and Chinese presence in Myanmar and Coco Island is a concern for India, who is looking for U.S support to deal with Chinese emerging power (Dixit, 2001:122).

In the quest for 'The New Great Game' (Cooley, 2012:1), the U.S, Europe and regional stake holders have activated a hegemonic race over energy rich Central Asian Region (Cooley, 2012:122). The Himalayas, Hindu Kush and the inaccessible terrain of Central Asian Region combined with the presence Pashtun, Tajik, Uzbek and Kurd warlords in Afghanistan who are an increasing the threat to energy transportation pipelines are the security concerns for the players (Woodward, 2010:264). The presence of extra regional forces in Afghanistan, and around Iran coupled with the Georgian incursion has put Caspian pipeline in a peril. Extra regional and regional key players must act to harmonies the Indian Ocean Region instead making efforts to dominate it. The harmonious waters can usher an era of development and security in the Indian Ocean Region and world.

\section{Heartland's (China) involvement in Mackinder's marginal crescent and sea power of Rim land}

In order to offset the effects of rising militarisation in Central Asian Region China has constructed a dynamic Gwadar Port (Mead's Bolg, 2012accessed on 11 Dec 2012) in Pakistan at the gate of the most important choke point; Hurmoz Start in the Indian Ocean which will provide China a base in proximity of Hurmoz to deal with U.S $5^{\text {th }}$ Naval Fleet. The Gwadar port will also provide the facility of being a hub for oil and gas pipelines linking to Central Asian Region to warm waters through silk route and Afghanistan. A marine capability at Gwadar has concluded sensitivities regarding Chinese geo-political aims in the arena. As highlighted by various stake holders possible Chinese militarisation only $500 \mathrm{~km}$ away from Hurmoz may offer hoary apprehensions about Beijing's "string of pearls" strategy because of Chinese strategic presence in the Indian Ocean. Gwadar Port as envisaged by China is conventional shipping facility to link landlocked Chinese with Indian Ocean SLOCs. Converting the commercial port into military bases will not only entail massive protection but also convincing Pakistan to tumble a geopolitical strategic balance between China and U.S. Chinese constructed Gwadar and Hambantota Ports have commercial value and pose no threat. The recent launch of Chinese aircraft carrier has added the anxieties for the U.S and its dependent ally, India over the military challenge springing from the fastest rising Asian giants. The China has accomplished assembly of on the new Chin -Kazakhstan energy pipeline in 2009 along China-Kazakhstan border to Caspian by filling it up from Tengiz Oil Field (Kazakhstan-China oil pipeline accessed on 11 Dec 2012).China's hierarchy feels taciturn to keep on subcontracting their national SLOCs to U.S and its supported Indian flotillas.

Chinese incursions in Asiatic monsoon region of Rim land. Chinese have crafted ingress in Myanmar, where China-South Korea syndicate is at threshold of concluding a fuel transporting contract with Myanmar involving several projects such as fuel expansion by construction of harbours and docks, development of oil plus gas 
terminus, road construction, and pertinent outlays. Energy channels are vibrant component of energy transportation. Launched by Chinese National Petroleum Corporation in partnership with Myanmar Oil and Gas Enterprise will strengthen the oil and gas conductive passage from the Middle East to main land China avoiding its security concerns at Malacca; a three km narrow choke point shipping choke point monitored by the U.S. China has recently announced plans to construct a $810 \mathrm{~km}$ long rail linkage between Ruili (China) and Kyaukphyu (Myanmar) via Muse whereas Thailand is involved in building Dawei Port (World Maritimes News 2012accessed on 11 Dec 2012). On completion, Dawei Port in Myanmar will have capability to handle and anchor vessels up to 300,000 tons. This continental infrastructural connectivity will link China with Indian Ocean via Vietnam. This port will surely reduce the cost and risk carrying energy supplies and other logistics to China Sea through Kra Isthmus instead of Malacca Bottleneck.

Chinese interests in Sri Lanka. China's initiative to grow its alliance and collaboration with Sri Lanka is prudent for the entire Indian Ocean Region. Chinese enterprises are constructing the Hambantota port in west of Colombo(Davidson, 2010:92). The foundation stone was formally laid in October, 2007 and construction by China Harbour Engineering Company actually started in January, 2008. Building of 1000-metre jetty will enable the harbor to serve as a business facility. By 2023, Hambantota will be beefed up by a natural gas refinery, aviation fuel stocking capability within dependent docks facilitating shipment capability combined with ship darning and building. Project envisions once completed it will assist as docking, bunkering and refueling facility with depth of $16 \mathrm{~m}$ comparing to $15 \mathrm{~m}$ of Colombo. Anew airport is also being constructed at Hambantota by expanding an amount worth U.S\$ 190 million and financial assistance will be provided by Chinese Ex-Im Bank. Various projects like expansion of road and rail infrastructure by spending an amount worth U.S \$ 348 million and Norochcholai Plant with an amount worth U.S\$855 million are also the part of Chinese ventures.

China in Nepal (Himalayas). Mushrooming Chinese influence is manifested by building communication infrastructure connecting both. China has devoted U.S \$ $3 \mathrm{~b}$ for a shared undertaking for expansion of Lumbini (birth place of Lord Buddha closer to Indian border) Express Way which will be place of global tourist attraction.

Chinese interests in Maldives and African Archipelago. Chinese are taking part in development of Maldives and are establishing the Chinese institutions and universities. Other Island like Seychelles, where Chinese President Hu Jintao visited in 2007, much to Delhi's surprise, Beijing is now training the small island nation's defense forces and providing military hardware such as turboprop aircraft for surveillance. India was also taken aback last year when Seychelles offered the Chinese Navy its territory for a base. Though Beijing never agreed but India got startled. That's why earlier this year Delhi extended a U.S $\$ 50 \mathrm{~m}$ of credit and U.S $\$ 25 \mathrm{~m}$ grant to Seychelles.

Chinese 'string of pearls' Policy. It refers to security of Chinese SLOCs extending from China to Sudan (Goldstein, 2005:17). SLOCs pervading bottle necks like Bab el Mandeb, Malacca, Hormuz and Lombok Strait are various geo-political marine facilities in South Asia. 'String of Pearls' pronounces expression of Chinese growing strategic impact by means of its determination to upsurge its way in harbours and airports combined with geo-political association to endeavor for having a "harmonious ocean".

Energy Security. SLOCs emanating, from Asiatic Monsoon Rim land to Suez is emerging as an energy concern for China. In 1993 it became net oil importer sand is responsible for $40 \%$ of world oil growth and since 2003 has become second largest consumer oil, increasing oil demand of 9.96 million barrels a day (Chua and Ashleigh Au, 2000:v-3.1-v3.33). Fifteen percent of Chinese oil needs are met through Sudan. China has concluded various oil field development contracts with Iran. Recent Surge of piracy in the proximity of Horn of Africa and situation in Darfur has bugged the China's policy to handle such aggressions. Indian worries that 'string of pearls' will cause a military handicap to it, may let China to grow associations with the other countries in the Indian Ocean Region, including littoral states like Pakistan. China like all other states have the right to protect its national interests by safeguarding its SLOCs in the Indian Ocean, from where $80 \%$ of its energy flows through U.S dominated Indian and Pacific Oceans. 'String of pearls' provides it the much needed security. Kra Isthmus will provide a secure and an alternative route instead of longer, vulnerable and a U.S dominated three $\mathrm{km}$ narrow choke point at Malacca in between Hambantota to Shanghai (Investments News and Commentary from Emerging Markets in Asia-China, India and ASEAN, 2009). 
- To extend its inspiration across ocean through clientele, capital, and geo-political partnership with U.S (Zeb Regional Studies Journal Vol I. XXII, No.1: 48, winter 2003-04) and Central Asia \& the Caucasus.

- Enhancing associations in Africa, Arabian Peninsula and Asiatic Monsoon thus entailing more fuel guarantees for its accomplishment of its aims.

- Arranging it to arise as overriding authority in next decade.

- Restricting China to be a regional naval power.

- Galvanising U.S-Pakistan ties; par Indian national interests (Hussain, Regional Studies Journal Vol.XXII.No.3:49(2004).

- Permanent access to Iranian mineral and energy reserves as it houses $10 \%$ of planet's established oil stocks and fourth largest oil stock policy (2012). In 2009 India implemented 16.5\% of India's oil from Iran. In 2005 Indian Oil companies operated Pars Gas Field. Indian announced an investment of U.S \$ 5 billion in development of off shore natural gas fields. India wants emerging Iran as a geo-political approach to Afghanistan and CARs. India is trying to grow Iran as a balancing pressure over Afghanistan- Pakistan ties.

- Iraq is third highest oil purveyor for India. India's multinationals at Yemen have attained license for drillings and exploration of blocks. Kuwait supplies $10 \%$ of Indian oil needs. Saudi Arabia is key oil purveyor, bookkeeping about $20 \%$ of its requirements. Consensual business both was US\$21 billion in 2010.

India must comprehend its limitations like poverty, fissiparous tendencies of its north east and its relations with all the neighbours including the Indian Ocean (Agnihotri AS and Ray, 26). It will be more prudent for the India to work in harmony with other regional states and powers of Indian Ocean instead of seeking help from U.S to influence all the littoral states of Indian Ocean and should work for better security and development of the region.

\section{U.S (outlaying islands) in Rim land and its ocean}

- The U.S perceives a comparatively varied variety of possible threats to its securities in the Indian Ocean Region, oscillating between pressures from regional power to non-state players. There are consistent safety worries, vacillating from SLOCs safety to increase in non-conventional weapons. The threat of Islamic expansion is a sour point; increasing profoundly.

- U.S distinguished China as a substantial geo-political anxiety in Indo-Pacific Region. A threat may ascend in Asia as Chinese are considered as sustained risk to U.S securities in Indian Ocean, including Pacific Rim.

- Substantial U.S defence spending slash worth U.S \$ 1.2twill consequently causes decrease in U.S potentials to pledge in the Indian Ocean region (US debate club accessed on 11 Dec 2012). The Asiatic 'pivot' lays more emphasis on U.S defence in the Indian Ocean Region as well.

- A decrease in dedicated U.S defence capitals and lack of British and French interests may cause power vacuum in Indian Ocean (Kamar, 2000: X). The vacuum is likely to cause a shift in U.S defence assets from the North to South Pacific by shifting 60\% of its naval fleet to Hawaii (Nate Gaddi, 2012, accessed on 11 Dec 2012). With the option of redeployment of its naval assets in the Indian and Pacific Oceans will now be most likely banking on the atoll of Diego Garcia as a hub for any kind of threat in the Indian Ocean Region.

- The large part of power vacuum needs to be filled by U.S allies like Indonesia, Australia and India, who can assume greater responsibilities for regional security in the absence of the U.S.

- Ensuring that U.S intentions are not endangered by countries like China and Iran.

- Ensuring the security of maritime chokepoints and SLOCs.

\section{Specific U.S concerns for chief regional states}

China. The concern of U.S as how to deal with emerging China in the Indian and Pacific Oceans is likely to continue till 2020. It will be prudent for U.S review its policies and to share with China. It will be imperative to understand as to what extent U.S can make compromises with a rising China and what the U.S really opinions about Chinese legitimate safeties in the Indian Ocean and Asia-Pacific regions. Any possible resistance with Chinese can lead to establishment of military bases and an augmented decisiveness concerning regional states, predominantly in South China Sea. It compels U.S to up hold its alliances in the Indo-Pacific Region.

India. A more vibrant and supportive India would be essential for U.S objectives in the Indian Ocean Region for a decade at least. Washington would like to urge India to be more familiar with U.S interests encompassing Myanmar, Iran and Afghanistan U.S would like India to stabilise Afghan situation. Washington would want India to draw its attention towards east, consequently supplementing and strengthening part as counterbalance to China. U.S envisages India to put pressure on China in the Indo-Pacific maritime realm.

Pakistan. Pak-U.S ties have been full of pricks yet it is excessively vital to be ignored. The U.S concerns for Pakistan in aftermath of its limited pull out the Afghanistan 2014 may change, considering the ground realities 
and safety corollaries; it will be prudent to keep it aboard. Keeping in view its potential to be a regional economic corridor between Indian Ocean and Central Asian Republics (Heartland) by 2020, its strategic location at a center of Pangea at the gate of $34 \mathrm{~km}$ narrow Strait of Hurmoz and still out of it, location of its strategic Gwadar Port, its standing being a nuclear influence combined Islamic expansionists, the U.S wants Pakistan to be on its side subject to concerns China and India. In the future, the U.S will continue to work with China, India, and Russia and possibly even with Iran.

Pakistan provides a shortest, established and a secure route to Europeans, East Asian and Pacific Nations to the great game via Gwadar Port. As the U.S has already degraded its aims in a war against terror in Afghanistan (Woodward, 2010:270), so the option of filling the power vacuum in Afghanistan by India after the U.S draw down in 2014 appears no more than a fallacy. Pakistan has the capability to safe guard its EEZ east of Hurmoz Strait to north east of Laccadive Sea. The security of SLOCs between Hurmoz Strait and Laccadive Sea hinges between India and Pakistan over the Kashmir issue. The U.S being the only super power may ignore these realities to its interests but will have to take pragmatic solutions to resolve this for the continuity of those interests.

Afghanistan. The U.S is now feeling exhausted due to the circumstances in Afghanistan and any hope of seeing is as an effective democracy, as was initially visualised a decade ago seems to be a far cry. In present scenario U.S will be aiming at protecting it as a 'quarantined' by collaborating with regional allies, especially Pakistan to suit the present scenario. By the year 2020 in the aftermath of U.S pull out, Afghanistan is likely to afford opportunities for U.S to be an economic corridor for Central Asian Reserves mainly through Gwadar Port.

Iran. A dominant U.S policy is averting it from attaining fissile arms with a view to a regime change by the support of westernised young generation. The U.S is very dubious to bout Iran's fissionable setups but will persuade to reinforce sanctions for accomplishing its aim to preclude it from obtaining the atomic weapon capability.

Indonesia. Though U.S-Indonesian associations have proved to be little undersised in past but are likely to improve because of Indonesian financial accomplishments and being part of Malacca Strait; the only three $\mathrm{km}$ narrow link between Indian and pacific Oceans. Drift in U.S-Indonesian ties can prove predictable to endure relationships between both entailing Indonesia to find a potent status within U.S alliances.

Australia. The futuristic key U.S interest should be to protect Australian ongoing sustenance for the U.S in the Indo-Pacific Rim land. Safeguarding Australian backing for U.S commerce and premeditated posture will lead to prominence. Australian backing for U.S in the region bordering both oceans will be prudent for U.S to counter China, who has planned Kra Canal as an alternative to Malacca Strait so in future of both countries could have divergent policies towards China in times to come. Any futuristic U.S issue with China can be a nerve testing situation however Canberra is unlikely to be away from Washington, in such situation there would be no major shift in the relationships.

The U.S should appreciate that the emerging globalisation is not only limiting the all the powerful and developing states but at the same providing opportunities to the developing states to safeguard their interests. The US should experience and learn to share in order to maintain its authority and economic strength. The concept of Zone of Peace and Freedom should have been followed in true esprit (Forbes, 1995:55).

\section{European involvement in Indian Ocean Region}

Any risk to European shipping in these SLOCs is clearly a shared security interest of European and Asian economies. The Indian Ocean Region, extending from the Suez Canal to Indonesian Archipelago, is of critical prominence for Europe too. However European interest in the region's maritime space and its security challenges are mostly linked to Bab el Mandeb and Hurmoz Strait. As a consequence, the European Union (EU) and other European countries that have territories in the Indian Ocean Region (France, Great Britain) are focusing eastwards will have to shares their trade across the region. Indeed, Europe has been principally thoughtful with its own neighbourhood and the war in Afghanistan.

The piracy at the Horn of Africa; south of Gulf of Aden in the Indian Ocean has been a rising threat to security(Ploch, 2010:7), international SLOCs and shipping its expansion in the Indian Ocean. Piracy is a complex issue that can only be addressed by combining political and diplomatic energies with armed and permissible action, support and strong international coordination. With all these tools at its disposal, the EU is in a unique situation to back the international efforts, and address the challenge through an inclusive approach. The EU help in expansioning of trade with CARs companies should collaborate with economic enterprises to encourage trade and enhancing fuel passage linkages. EU and CARs have common aims to enhance energy safety and transportation as a vital facet for regional safety. Apart from oil and gas hydro-power generation and 
its management are critical in leading to permanence and affluence in CARs, Afghanistan and Pakistan. The availability of energy resources has meaningfully augmented the role of CARs as energy managers and transferring states. Fostering energy exploration would add mainly for energy provisions being helpful towards enhancement. Gas provisions are of prime value to EU. Chief components for a prolonged collaborations basing on unanimous facets and mutuality can be recognized in times to come; exploitation of energy resources from CARs yields for a considerable and continued stock with pragmatic procedures answering for all elements of their energy segments and easing entree to most established market places. The EU should focus on exploitation and up gradation of the prevailing hydrocarbon energy infrastructure via New Silk Route in order to secure fuel supplies; EU should ease the expansion energy passage grids (Karp, Kratz, Ynn Szwaja and Frausto, 2007:101).This will add to regional and extra regional safeties and collaboration with a view to enhance trade for CARs.EU can diplomatically assist CARs in establishing Caspian - EU energy passageway.EU should encourage creation of a pragmatic Central Asian energy market and stock sharing.

\section{NATO in Eurasia}

NATO can pursue defense and security cooperation on wide range of issues. NATO has endorsed Internet linkage between the countries of CARs and Caucasus, called as 'Virtual Silk Highway' venture (Sridhari and V.Iyer, 2012:173). The level of participation varies from country to country. Kazakhstan is the most progressive in collaboration since 2006. Kyrgyzstan joined in Planning and Review Process in 2007. Other three have limited ties with NATO; however CARs have recognised political signature with NATO. CARs feature much more prominently on NATO's security agenda. It brought to an acute awareness of the region's importance to the security and constancy. Germany is establishing an air base in Uzbekistan (Coskum and Cusko, 2009:366). The U.S has similarly one in Manas in Kyrgyzstan and also had a base in Uzbekistan at Karshi-Khanabad (Cooley, 2012:120). France has a force based in Kyrgyzstan with a logistics center in Tajikistan (Bensahel, 2003:11), whereas Netherlands is using Bishkek airbase for F-16 airplanes. During NATO conference at Turkey in 2005 affirmed the leadership about CARs value by terming it as an area of 'special focus' and assigned a liaison officer Almaty with assignment of supporting CARs at in NATO. A office of Secretary General's Special Representative for Central Asia and the South Caucasus has also been created.

\section{British (offshore island) in marginal lands and waters}

Half of naval resources are located in the Indian Ocean. The $25 \%$ of Britain's troops in Afghanistan are part of navy. Consequently financial limitations have compelled British Naval Forces to collaborate with allies. Due heavy defence budget cuts and persistent operating placements, British Navy is challenged by intensifying stresses on its restricted capitals. Royal Navy's contributions in Asia have highlighted the significance of Indian Ocean.

Recently, British have adopted policy 'Swing', entailing necessity for British Navy to remain malleable with a view to accomplish wide ranging tasks assigned in Indian Ocean Region. British Navy was compelled to deal with countering terrorism, wars in Asia, calamities like Tsunami, and crises in North Africa. Original view as to how the Royal Navy should adapt the changing operational environments. At present about 2000 naval sailors are positioned, corresponding to over a dozen warship crew which are $25 \%$ British Force positioned in Afghanistan. British securities in Indian Ocean Region are substantial, which compel British Navy to operate in the Persian Gulf and the Indian Ocean for well over three decades. British are collaborating with regional partner nations involving security assurance. It operates from headquarters either Northwood in England or Bahrain. British Navy also a part of counter-piracy task force operating close to the Horn of Africa through NATO, EU and coalition maritime forces (McKnight and Hirsh, 2012:2).In the Persian Gulf British Navy maintains four mine hunters, a LSDA, a tanker two warships and a submarine which is a very high percentage of units that are deployed in Indian Ocean Region.

The Indian Ocean is vital to UK as it procures $60 \%$ of its liquid natural gas from Qatar. Choke points in Indian Ocean Region such as the Hormuz Straits and Suez Canal are all vital to Britain's energy supplies. Indian Ocean Region houses more than 200,000 British citizens. Despite the sort of immediate and publicised reductions the British Navy is still skilled of facing the Future Naval challenges. The reduction has been challenging, but it has made British Navy to work smarter. In the distant future British Navy is aiming at a programme for commissioning of new vessels.

\section{Russian interests in Indian Ocean}

Since the disintegration of USSR, Russia inherited $90 \%$ and $70 \%$ of territory (Malik, 2001:45). Since pull out of Russia from Afghanistan and latest 'war on terror', scenario Russian are pursuing strategic character in Central Asia. Moscow has enhanced its relations with China, Iran, Afghanistan and Pakistan (Zeb Regional Studies Journal Vol. XXII, No.2: 48, spring 2004). Considering the NATO's expansion to the East including the recent NATO's decision to deploy the missiles on the eastern border of Turkey in Asia, its concerns about 
Ukraine, global race to Central Asian Resources and U.S presence in CARs, Moscow is improving its relations in South Asia particularly Pakistan. Islamabad can provide Russia with a shortest access to the much desired warm waters through strategically located Gwadar Sea Port at the gate Hurmoz Strait. The access to warm water of Indian Ocean will allow Russia to join in the race for African resources and to improve its economy by transporting its oil and gas to even west through the Indian Ocean so as to offset any NATO pressure on energy supplies to its neighbouring East Europe.

The Europe including NATO and EU, who are already finding it difficult to maintain their economic and strategic unity should have harmonious policies and designs towards developing countries, specially littoral states of Indian Ocean so as to make them strong enough to develop and share their resources.

\section{Round for Ascendency}

It includes three broad categories of states those are endeavouring for authority and enhancing the maritime interests in Indian Ocean; firstly; chief stake holders such states seek dominance in entire oceanic region. Convincingly, China and U.S have capability and determination to contest with the littoral states. Secondly; the regional players who seek domination primarily in relevant oceanic portion their securities, such countries include Australia, Indonesia, Iran, Malaysia, Russia, South Africa, South Korea, UK, India and Pakistan. Thirdly; the Passive players like Bangladesh, Maldives, Mozambique, Myanmar, Oman, Sri Lanka, Yemen and Remote overseas islands territories in ocean can supported to work for common interests. Such states will not be able to exert an independent pressure and will be wooed by the big players to meet their strategic objectives. It will be prudent to make the Indian Ocean a harmonious ocean for a prudent and just development of all the littoral states.

\section{Dominating navies of heartland, offshore and outlying islands}

U.S fifth naval fleet. It maintains a noticeable and an influential force to counter and discourage fears to its interests in the Arabian Sea and Persian Gulf span of Indian Ocean (Daniel, 2003:50).The US Naval Forces Central Command is responsible for operations in the Middle East with headquarters in Bahrain.

U.S seventh naval fleet .Seventh Fleet is the largest among deployed U.S comprising of 50 to 60 ships, 350 aircraft and 60,000 naval and Marine Corps troops. The fleet is operational in Indo - Pacific Oceans with headquarters in Yokosuka, Japan (Henry, 2002:11). The US Navy currently has 285 ships with about half of these deployed in the Pacific .As a re-positioning, U.S announced that majority of its naval fleet comprising about six aircraft carriers will be deployed in Pacific by 2020 as part of new strategic focus on Asia. Recent deployment of U.S forces will break up the fifty - fifty split by assigning $60 \%$ of its naval vessels being moved to the Asian region.

Striving Indian Navy in Indian Ocean. Spouting out of ground through pipelines, oil reaches its consumers via bottlenecks in Indian Ocean. The narrow Hormuz Strait; having width of only $34 \mathrm{~km}$ via which supertankers haul away 17 million barrels oil per day. Vessels, mostly belonging to China, Japan and Indonesia sail across the narrow span of ocean which is only three $\mathrm{km}$ wide; Malacca Strait, bordering Indian and Pacific Oceans. International security analysis's value the safety of the two choke points, but stay confident over the rest of the ocean. Indian Navy along with U.S operates between Qatar and South China Sea. Indian Navy also guards two of its offshore island chains of Andaman and the Lakshadweep Islands. India has opened a permanent base at Lakshadweep due to piracy incidents. Indian Navy has in recently captured numbers of pirates and thwarted several attacks in collaboration with Pakistan Navy. Since 2004 with the help of U.S Indian Navy is trying to have some influence in the Indian Ocean and despite being the largest littoral state Indian Navy is finding it difficult. Pakistan Navy is at the gate of most important choke point in the Indian Ocean, the energy rich Hurmoz Strait whereas Malacca Strait being the second most important choke point is far away from the Indian reach. Chinese concerns are enforcing upon additional challenges for Indian Navy to have influence over Malacca Strait is a facet drifting the Indian navy further away from it. Chinese presence at Hambantota and the Great Coco Island in the Bay of Bengal is further enhancing Indian security concerns.

\section{Disputes in Rim land and Heartland waters}

Chagos Archipelago

In 1965, British occupied Chagos Archipelago from Mauritius, and the islands of Aldabra, Farquhar and Desroches from the Seychelles, the complete archipelago became the British Indian Ocean Territory, a territory for which the UK had strategy to use its for joint UK-U.S military bases and accomplishments. Total private property was bought Chagos islands during 1966, and complete population of Diego Garcia, was compellingly transferred to Mauritius. The Seychelles' islands were then returned in 1976, and since then, the British Indian Ocean Territory only consists of Deigo Garcia which is now a huge US military base as U.S 
protected a lease from the British in response to selling of Polaris nuclear weapons at a reduced price to UK. The former Deigo Garcia dwellers, residing in Mauritius and the Seychelles, continued to contest for their motherland and won suits in Court of UK and payments worth UK£14 min 2000, but the Chagossians have not yet been allowed to their islets because of a 'Royal Prerogative', and constitutional amendments for its continuous occupation. Although Britain government has decided to concede the archipelago to Mauritius once U.S government will agree to vacate it, which seems to be very far cry. Mauritius claims that the islets were taken over illegally $\mathrm{f}$ in 1965, and claim complete dominion over them, and Seychelles claims partial authority over a few of the islets. The British withdrawal from Diego Garcia and subsequent sale of it to the U.S, in the heart of Indian Ocean in 1968 drew international attention against the U.S ambitions for military base at Diego Garcia (Kamar, 2000:X).

\section{Macclesfield Bank}

Macclesfield Bank is an enormous subsurface cluster of ridges and cays which is claimed and presently occupied by the Philippines. Being the planet's biggest atoll it encompasses $6,501 \mathrm{sqkm}$. It is situated in close proximity to Paracel and Spratly Islands, which are jointly called as South Sea Islands. China and Taiwan prerogatives autonomy over it as part of its Paracel, Spratly, and Zhongsha Islets.

\section{Paracel Islands}

Housing only 8 Chinese soldiers the cluster of thirty cays and sandbars are enclosed by oil deposits. China, Taiwan and Vietnam have unanimous claims for authority for centuries, which turned into a war after the French pull out in 1956, and the dispute concluded in China defeating Vietnam in the 1974 Battle of Paracel Islands (Ellaman, 2011:145). The clash over these islets and cays is linked with the disagreement over Spratly Islands in its close proximity.

\section{Scarborough Shoal}

Physically located close to disputed Spratly and Paracel Islets, sand mount has similar dominance concerns like its neighbouring islets. The islets are controlled by Philippines and Chinese place rightover Paracels, Spratlys, and Zhongsha Islets, Taiwan pronounces sovereignty too.

\section{Spratly Islands}

The Spratly Islets are a small archipelago consisting of 660reefs, islets and atolls located in the South China Sea with no habitation for several epochs. Much of these islets are claimed enthusiastically by China, Taiwan, Malaysia, Philippines, Vietnam and Brunei. All these claimants less Brunei have military bases over 45 different islets.

\section{Khuriya Muriya Islands}

The Khuriya Muriya Islands are a cluster of five islands in the Arabian Sea, $40 \mathrm{~km}$ off the southeastern coast of the Sultanate of Oman. The islands form part of the province of Shalim and the Hallaniyat Islands in the governorate of Dhofar. In 1854 the sultan of Muscat ceded the islands to Britain and in 1868 they were attached to the Aden Settlement. On 30 November 1967, Lord Caradon, the British Ambassador to the United Nations, proclaimed that in agreement with the desires of the natives, the islands would be reverted to Muscat and Oman.

\section{Ligitan}

Is an islet in Sabah situated in the close proximity of Borneo as part of Celebes Sea. Previously it has been a bone of contention between Malaysia and Indonesia, which was settled by International Court of Justice in 2002 by ceding it and Sipadan to Malaysia basing on the status of "effective occupation" exhibited by latter's forerunner and nonappearance of any more grander name.

\section{South Talpatti Island}

South Talpatti is a trivial unpopulated ridge in Bay of Bengal in the South of Ganges-Brahmaputra Delta. It appeared on the sea surface as a result of 'Bhola Cyclone' in 1970 and at later vanished in little time. Both Bangladesh and India claim dominance over it due to the possible availability of energy resources.

\section{Sir Creek}

It is a $96 \mathrm{~km}$ long narrow water incursion which is undecided among India and Pakistan in Kutch. Creek opening into the Arabian Sea, distributes Kutch between India and Pakistan. Originally and locally it is called 'Baan Ganga', which was later named after the British officer. It is situated in the unpopulated marshlands of Pakistan but India unjustly claims. 


\section{Kashmir issue}

Situated between Asiatic Rim land and Heartland Kashmir is a mountainous terrain part of the great Himalayas mountain range. Kashmir being a hundred percent Muslim dominated area was to be part of Pakistan since the partition of sub-continent in 1947 but India forcefully occupied it and since than four wars have been fought over Kashmir between two arch rival nuclear littoral states. Pakistani Gwadar Port is located at the gate of the most important and energy rich choke point; Hurmoz Strait in the Indian Ocean. Any conflict between two neighbouring littoral states can put the security of energy transporting SLOCs between Hurmoz Strait and Laccadive Sea in jeopardy as it happened during 1999 war between India and Pakistan.

It is prudent for all the littoral states of Heartland in Indian Ocean to resolve the disputes in a pragmatic manner so as to avoid the efforts which are being wasted to dominate these areas and islands. The resources and efforts should be made for timely resolution of these disputes for better regional securities, economies and development.

\section{Analysis}

- Certain Indians are alarmed over the string of pearls will put India to a military handicapped. Absence of grand Indian policy might let China to grow associations with littoral nations of Indian Ocean so it will be compelling for U.S to enhance its alliance with India to counter Chinese inspiration in the Region.

- Chinese base constructing determination is principally defensive in nature which is designed to offset Chinese SLOCs weaknesses by positioning Peoples Liberation Army's Navy assets to challenge rivals. China's policy makers have supported naval bases to secure Chinese commercial securities in foreign parts, especially in Indian Ocean Region.

- The South Asian ports combined with the conduits feeding China will allow its vessels to unload oil avoiding bottle neck in the Eastern Indian Ocean. Such measures would diminish Chinese dependence over vulnerable SLOCs via Malacca 'chokepoint' where U.S navy can monitor its energy flow.

- Every country reserves the right to grow its diplomatic associations in neighbourhood and in geo-political zones. Chinese are perusing a vibrant policy to profess itself as a reliable associate of nations nearby India. Pakistan being a trusted friend can be helpful to develop strategic stronghold around India.

- Improving of the Karakoram Corridor will allow China a reach out Arabian Sea and Persian Gulf. Connecting energy transporting network via Silk Corridor, which will pragmatically develop Chinese military position in Tibet contrary to India and opposing NATO eastern tiptoe near Chinese boundaries. The NATO decision to deploy missile base in eastern Turkey is a point in case. Chinese are collaborating in various projects in Pakistan, which provides a strategic opportunity for China to pressurise the U.S embedment Afghanistan while being at 'strategic pressure point' of Gwadar Port at the gate way of Hurmoz.

- Chinese are constructing a signal intelligence setup on Great Cocos Islands only $241 \mathrm{~km}$ away from Andaman Islands allowing China to screen Indian communications and missile bases at Orissa.

- Myanmar's Sittwe Port, Coco Island are key localities linked to China's concerns in Myanmar with whom India shares $1600 \mathrm{~km}$ of boundaries. Myanmar also functions as an entry to South East Asia while being on the eastern flank to Bay of Bengal.

- The previous Bangladesh had offered China to take full advantage of it. Recently China and India are tussling about Nepal. China has enhanced noticeable impact over the Maoist. India is also unwilling to lose its clout in Nepal.

- Pakistan is currently involved in counter insurgency operations on its Afghanistan border territory with U.S impact. Pakistan's support is not presently accessible to China because of U.S presence in Afghanistan. Gwadar Port, which was constructed with Chinese help, is being managed by Singapore based Port Singapore Authority. China-Central Asian- Gwadar linkage is still awaited because of U.S and Indian biased Afghan government.

- The complete world is viewing Chinese conflicts in South China Sea and East China Sea. Whereas U.S and India are observing these with specific anxieties. U.S and India have no territorial claims but South China Sea is being viewed "as an antechamber of the Indian Ocean," which has raised the concerns in Beijing's likely to its navigational which is to foster ties with littoral states.

- The real alternative for India is to increase its dependency on the U.S. Despite all the exaggeration in New Delhi about "non-alignment" policy makers identify that collaboration with Washington can best thwart against rising China. This is something that Delhi and Washington will have to seriously think about as the balance of power alters in the Indian Ocean Region.

- It is fact that Pakistan provides a shortest, established and a secure route to Europeans, East Asian and Pacific Nations to the great game via Gwadar Port and Pakistan has the capability to safe guard its EEZ and SLOCs beginning from the Hurmoz Strait to Malacca Strait; the oil hub and energy corridor for the Indian and Pacific Oceans. The security of waters between Hurmoz Strait and Laccadive Sea hinges between India 
and Pakistan over the Kashmir Issue. It is the time that UN and the regional powers must resolve Kashmir all the disputes in the strategic Rim land so as to have safe, developing and secure SLOCs.

- NATO and EU can play a dominant role in the Mackinder's 'Pivot Area' of Heartland (Central Asian Region) and the neighbouring Rim land (Afghanistan) for better peace and energy securities of the region in particular and world as whole.

- China and Thailand have already planned to dig canal across the Kra Isthmus linking South China Sea the Bay of Bengal. However Kra Canal will link South China Sea Bay of Bengal, thus securing it SLOCs against US 7th Fleet in Malacca Strait and Pacific Ocean.

- Mackinder's doctrines of Heartland and Rim land envisaged and evaluated in early twentieth century are still proving to be potent. The Heartland which lies Pangea extending from Volga to Yangtze and Himalayas to Arctic is still potent and true to say that:-

$>$ Who rules East Europe commands the Heartland

$>$ Who rules the Heartland commands the World-Island

Who rules the World-Island commands the world

- Tri-region division of Heartland into the European coast land, Arabian-Middle Eastern desert land and Asiatic monsoon land is diminishing in swelling globalisation.

- Considering its economic problems leading to unemployment of millions of its youth. In 2000 U.S had budget surplus of U.S \$ 236 billion which was converted into budget deficit worth U.S \$ 565 billion in 2004(Rajeev, 2013). While losing its influence in Indian Ocean and the much required stability in the region, U.S must end this war on terror which it started and must review its supremacy in the world (George, Soros, 2004)

- Since the Russian economic and political failure to develop Russian Far East it has been forced to turn towards Beijing and has accepted the role of its junior partner to consolidate on a new economic and security order in Asia. With China redefining Asian Security and U.S enhancing its influencing in APR the economic security seems disturbed. Both powers must manage this complex set of diplomatic and relationship in IOR for a prudent and peaceful global order.

- Chinese tiptoe in Atlantic Ocean at Terceria Island in Azore Archipelago and at Casablanca Port in April 2013 is being viewed as a concern by U.S as it envisage it as an Chinese effort to not only the influence the Atlantic Ocean in response to U.S planned presence in South Pacific by 2020 but also an economic opportunity for China, Europe and Africa. China needs to enhance its diplomatic relations and economy influence in Europe for which it needs to have some foot hold through naval presence in Mediterranean Sea and enhancing it further to Atlantic Ocean. After having securing a base at Gwadar China will emphasis more towards Horn of Africa and Suez otherwise it will have to wait for snow to melt at North Pole to undertake a very long route to reach Mediterranean and Atlantic through North Sea. China is already enhancing its influence in proximity to U.S and Western Europe and Greenland.

- Iran needs to enhance its trade by shipping energy resources across the continent to Africa and Europe hence requiring a naval presence in Atlantic Ocean which may also reduce the U.S military influence over it. It may not be able to achieve this object as a solo flight and may look up to some regional force for the assistance may it be diplomatic or military. Iran has planned for significant naval presence in Atlantic in 2014 where as its $24^{\text {th }}$ naval fleet of warship is already located at the Chinese Port.

\section{Conclusion}

There is 'dynamic power vacuum' in Indian Ocean hence creating it an 'arc of instability' .U.S is believed to be an only super power, however, in the distant future the space is likely to be encroached upon by China which is fast emerging as a super power. Securing of space in Region by China will add to its insecurities. At present Sino-Indian bilateral trade, which is chiefly carried has risen from U.S \$ 14 billion in 2006 to U.S 41 billion in 2010 and this facet can enhance collaboration between both to ensure SLOCs security in oceanic region.

China is pursuing a strategy of keeping its Sea Lines of Communications secure by pursuing the 'String of Pearls' for its energy securities in a U.S dominated Indian and Pacific Oceans. The recent Indo-U.S strategy to work in collaboration to dominate Indian Ocean gives the right to all littorals states to safeguard their strategic interests. Apart from securing the port along the coast from Hong Kong to Cape Agulhas, China has the right to construct Kra Canal linking South China Sea and the Bay of Bengal, hence securing it SLOCs in presence U.S $7^{\text {th }}$ Fleet in Malacca Strait and East Pacific Ocean.

Noticeably it is necessary for U.S to review its geo-political role in Indian Ocean. Consequently there are worries about the increasing Chinese influence. The U.S is trying to keep its sole status of super power. China is probing for resources to sustain their drive to become global power. Historically, it is the search for 
energy resources that has led to the establishment of realms. The U.S, China and India with U.S support are not looking for territorial conquests but to bring States under their influence to backing their finances and geostrategic interests. In order to have 'Harmonious Water' as envisaged by the Chinese President the U.S must revisit its policy of controlling the Indian Ocean through India, Indonesia and Australia to distillate across Pacific 'Ring of Fire' to counter China. International and regional key players must act for harmonizing the SLOCs of Indian Ocean instead of dominating those. The harmonious waters can usher an era of development and security the Indian Ocean Region and world. The developed nations like US and forums likes NATO, EU and SCO can help and influence theses littoral states to resolve their disputes for a developed and a harmonious Indian Ocean Region.

\section{Reference}

[1] Alexander Cooley (2012) Great Games, Local Rules: The New Great Power Contest in Central Asia. London: Oxford University Press.

[2] Alvin J. Cottrel, Watter F. Hahn (2000) Naval Race or Arms control in the Indian Ocean? : Some problems in shipping. New York: National Strategy Info Center.

[3] Avery Goldstein (2005) Rising to the Challenge, China's Grand Strategy and International security. California USA: Stanford University Press.

[4] Basahrat Hussain (2004). Indo-Afghanistan Relations: Pre\& Post-Taliban Developments. Regional Studies Journal Vol.XXII.No.3:49.

[5] Benze Balamir-Coskum, Birgul Demirtas-cusko (2009) Neighbourhood Challenges: The European Union and its Neighbours. USA: Universal Publishers.

[6] Bob Woodward (2010) Obama's Wars; The Inside Story. UK: Simon \& Schuster UK Limited.

[7] Bruce A. Ellaman (2011) Naval Power and Expeditionary Wons: Peripheral Campaigns and News threats of naval warfare. USA: Routledge.

[8] Cagri Hakoz, Sridhari and Ananth V.Iyer (2012) Managing Supply China as the Silk Road: Strategy Performance, and Risk. USA: CRC Press.

[9] Christopher M. Davidson (2010). The Persian Gulf and Pacific Asia: From indifferences to interdependence. UK: C. Hurts \& Co Publishers.

[10] David Blumental, Tju Liang Chua and Ashleigh Au (2000) Dong Business in China: Upstream oil \& gas in China Report. China: Jurs Publications, PP. V-3.1-V-3.33.

[11] George, Soros. The Bubble of American Supremacy, Correcting the Misuse of American Power. United States of America: Public Affairs, 2004.

[12] Hafeez Malik (2001) Pakistan's Relations with the Soviet Union and Russia. Pakistan: OUP Press.

[13] Investments News and Commentary from Emerging Markets in Asia-China, India and ASEAN (2009) Kara Canal/ India Ocean/ South China Sea Project To Be Re-visited. Available at www.2point 6 billion.com/news/2009/03/18/ Kra-Canal-Indian-Ocean-1250. Html (accessed on 11 Dec 2012).

[14] Ivan Karp, Corinine A. Kratz, Ynn Szwaja, Tomas Ybarra-Frausto (2007) Mesume Friction: Public Cultures/ Global Transformations. USA: Duke University Press.

[15] Jyotindra Nath Dixit (2001) India’s Foreign And its Neighbours India: Gayan Publishing House.

[16] Kamal Kumar (2000) Indian Ocean as a zone of peace problems and prospects. India: APH Publishing Corporation.

[17] Kamal Matinuddin (2003) India- Pakistan Standoff Regional Studies Journal Vol. XXI, No.3: 27-28

[18] KMG (2011) Kazakhstan-China oil pipleline.www.King.kz/en/manufacturing/ oil/ Kazakhstan-china/ (accessed on11 Dec 2012 ).

[19] Lauren Ploch (2010) Piracy of the Horn of Africa. USA: DIANE Publishing.

[20] Mark Henry (2002) the US Navy in World War II. USA: Ospery Publishing.

[21] Nara Bensahel (2003) the counter terror coalitions: cooperation with Europe, NATO and issue 1746. UK: Rand Publications.

[22] Nate Gaddi (2012) Hawaii Could Benefit from US/China Tersias. Available at bigislandnow.com/2012/09/18/hawai-could-benefitfrom-uschina-tensrds/ (accessed on 11 Dec 2012).

[23] Port Singapore Authority (1965) General Information on the port of Singapore. Singapore: Singapore Press.

[24] Pradeep Sharma (2000) Economical Political Geography. India: Discovery Publishing House.

[25] Radam Terry McKnight, Micheal Hirsh (2012) Piraye Alley: Commanding Task Force 151 off Somalia. USA: Naval Institute Press.

[26] Rick Gold State (2012) Iran's Warrning to oil Market Fails to send price Higher. The New York Time, 23 October, 12.

[27] Raj Narain Misra (1986) Indian Ocean and India's security. India: Mittal Publications.

[28] Rajeev Sharma (2013) Will China's takeover of Pak's Gwadar port be a game changer? .First Post (India), 4 February, 2013

[29] Rizwan Zeb (Spring 2004) USA in Central Asia \& the Caucasus. Regional Studies Journal Vol . XXII, No.2: 48

[30] Rizwan Zeb (Winter 2003-04) USA in Central Asia \& the Caucasus. Regional Studies Journal Vol I. XXII, No.1: 48.

[31] R.J. Daniel (2003) the End of an Era-UK.UK: Periscope Publishing.

[32] Robert Hanks (1980) the unnoticed challenge: Soviet maritime strategy and global choke points. Virginia: Institute for Foreign Policy Analysis.

[33] Siamack Shojai (1995) The New Global Oil Market: Understanding Energy issues in the world Economy. USA: Green Wood Publishing Group.

[34] Syed Zahoor Qasim (1998) Glimpses of the Indian Ocean. India. Universities Press.

[35] Sir Arnold Talbot Wilson (1933) The Suez Canal, its past, present and future. Oxford: Oxford University Press.

[36] The Heartland Theory and present day-Day Geo political Structure of Central Eurasia. Availableat www.Silkroadstudies.org/new/doc/publication/1006Rethinking-4.pdf (accessed on 11 Dec 2012).

[37] U.S News, Debateclub. Are cuts to defense Budget Neccsary? (2012) Available at www.usnews.com/debate-club/are-cuts-to-thedefense-budget-necessary (accessed on 11 Dec 2012).

[38] Vivion Louis Forbes (1995) the Maritime Boundaries of the Indian Region. Singapore: Singapore University Press.

[39] Walter Russell Mead's Blog (2012) China to Add Pakistan's Gwadar Port to String of Pearls. Available at Bolg the-americaninterest.com/wrm/2012/08/31 china-to-add-pakistan-gwadar-port-to-string of pearls/ (accessed on 11 Dec 2012).

[40] World Maritimes News (24 $4^{\text {th }}$ Jul 2012) Myanmar: Dawei Port Development Program Move India.worldmaritime.com/archives/62050 (accessed on 11 Dec 2012). 


\section{Author}

Dr. Hasan Yaser Malik holds Master Degrees in Warfare Studies, International Relations and Special Education. He has done his Ph.D. in International Relations. He has been part of UN and is a Chartered Member of Institute of Logistics and Transportation (UK). He has contributed in eminent journals. 